\title{
Genetic Correction of Dystrophin Deficiency and Skeletal Muscle Remodeling in Adult MDX Mouse via Transplantation of Retroviral Producer Cells
}

\author{
Ariberto Fassati, ${ }^{\star \ddagger}$ Dominic J. Wells, ${ }^{\S}$ Patricia A. Sgro Serpente, ${ }^{\star}$ Frank S. Walsh, ${ }^{\ddagger}$ Susan C. Brown, ${ }^{\star}$ Peter N. Strong, \\ and George Dickson*

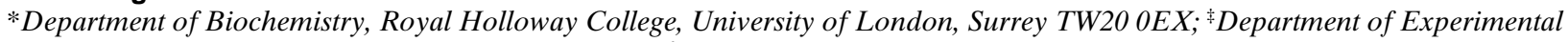 \\ Pathology, UMDS Guy's Hospital, London SE1 9RT; ${ }^{\S}$ Gene Targeting Unit, Departments of Pharmacology and Clinical Neuroscience,

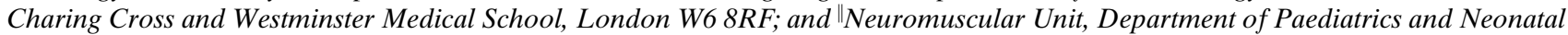 \\ Medicine, Hammersmith Hospital, London W12 ONN, United Kingdom
}

\begin{abstract}
Duchenne muscular dystrophy (DMD) is an X-linked, lethal disease caused by mutations of the dystrophin gene. No effective therapy is available, but dystrophin gene transfer to skeletal muscle has been proposed as a treatment for DMD. We have developed a strategy for efficient in vivo gene transfer of dystrophin cDNA into regenerating skeletal muscle. Retroviral producer cells, which release a vector carrying the therapeutically active dystrophin minigene, were mitotically inactivated and transplanted in adult nude/mdx mice. Transplantation of $3 \times 10^{6}$ producer cells in a single site of the tibialis anterior muscle resulted in the transduction of between 5.5 and $\mathbf{1 8 \%}$ total muscle fibers. The same procedure proved also feasible in immunocompetent $m d x$ mice under short-term pharmacological immunosuppression. Minidystrophin expression was stable for up to $6 \mathrm{mo}$ and led to $\alpha$-sarcoglycan reexpression. Muscle stem cells could be transduced in vivo using this procedure. Transduced dystrophic skeletal muscle showed evidence of active remodeling reminiscent of the genetic normalization process which takes place in female DMD carriers. Overall, these results demonstrate that retroviral-mediated dystrophin gene transfer via transplantation of producer cells is a valid approach towards the long-term goal of gene therapy of DMD. (J. Clin. Invest. 1997. 100:620-628.) Key words: Duchenne muscular dystrophy • dystrophin • retroviral vectors $\bullet$ muscle stem cells $\bullet$ gene therapy
\end{abstract}

\section{Introduction}

Duchenne muscular dystrophy (DMD) ${ }^{1}$ is an X-linked recessive disease affecting 1 out of every 3,500 liveborn boys. It is

Part of this work was presented at the 1996 Cold Spring Harbor Laboratory Meeting on Gene Therapy.

Address correspondence to Professor George Dickson, Department of Biochemistry, Royal Holloway College, University of London, Egham, Surrey TW20 0EX, United Kingdom. Phone: 44-1784443545; FAX: 44-1784-434326; E-mail: g.dickson@rhbnc.ac.uk

Received for publication 27 November 1996 and accepted in revised form 22 April 1997.

1. Abbreviations used in this paper: DAG, dystrophin associated glycoproteins; DMD, Duchenne muscular dystrophy; dys, minidystrophin (229 kD); IRES, internal ribosome entry site; N-CAM, neural cell adhesion molecule; Neo, neomycin phosphotransferase; TA, tibialis anterior.

J. Clin. Invest.

(c) The American Society for Clinical Investigation, Inc. 0021-9738/97/08/0620/09 \$2.00

Volume 100, Number 3, August 1997, 620-628

http://www.jci.org caused by mutations in the dystrophin gene, resulting in the absence of dystrophin and related proteins in skeletal muscle and other tissues $(1,2)$. In the early phase of the disease, skeletal muscle of DMD patients is characterized by an ongoing process of degeneration and regeneration which is later followed by exhaustion of the regenerative capacity, fibrosis, phagocytic infiltration, and eventual disruption of the muscle tissue architecture (2). The pathological process involving skeletal muscle manifests clinically with progressive muscle weakness and atrophy, confinement to a wheelchair before the age of 12 and eventual death due to respiratory insufficiency (2). No effective therapy is available at present and dystrophin gene transfer has been proposed as a possible approach to treat DMD.

The process of skeletal muscle degeneration and regeneration observed in young DMD patients and in the analogous dystrophic $m d x$ mice and $x c m d$ dogs $(3,4)$ is sustained by the muscle stem cell (or satellite cell) population. Muscle satellite cells are mononucleated cells located along the myofibers between the sarcolemma and the basement membrane. They are normally quiescent but can, under appropriate stimuli, proliferate and fuse to form new fibers along the structural framework provided by the basement membrane of damaged fibers $(5,6)$. We have shown previously that the transplantation of retroviral producer cells in adult nude $/ m d x$ mice leads to the efficient in vivo infection of activated satellite cells and the appearance of large numbers of transduced myofibers (7). Furthermore, at least a proportion of the transduced satellite cells survived as stem cells and participated in the process of muscle regeneration in the long term (7). Retroviral producer cell clones releasing a vector which contains the therapeutically active $6.3-\mathrm{kb}$ dystrophin minigene (8) have now been constructed and transplanted into regenerating skeletal muscle of adult nude $/ m d x$ and $m d x$ mice under shortterm pharmacological immunosuppression. We have attempted not only to evaluate the efficiency of retroviral-mediated dystrophin gene transfer in skeletal muscle, but also several other important issues related to the pathophysiology of dystrophic muscle which are relevant to future applications of gene therapy.

A variety of studies have shown that the full-length and the Becker-type 6.3-kb dystrophin cDNAs are able to prevent the onset of dystrophy when expressed in the $m d x$ mouse muscle. Such studies were based on dystrophin expression in transgenic $m d x$ mice or on adenoviral-mediated dystrophin gene transfer in newborn $m d x$ mice (9-14). However, what is effective in preventing muscular dystrophy may not necessarily be effective in reversing existing pathology and disorganization of the extracellular matrix or changes in the normal muscle architecture may have irreversible pathological effects. Few studies have addressed the problem of the therapeutic efficacy of the dystrophin cDNAs when administered to young or adult $m d x$ 
mice $(15,16)$. Such an experimental setting is closer to the clinical scenario since the pathology of skeletal muscle observed in very young DMD patients is similar to the one observed in adult $m d x$ mice $(2,3)$.

A mosaic population of dystrophin competent and incompetent satellite cells is present in skeletal muscle of female DMD carriers due to the random inactivation of one of the two X-chromosomes in early embryonic life (17). Since mature muscle fibers are syncytia derived from the fusion of embryonic myoblasts, in young DMD carriers there are myofiber segments which do not express dystrophin and are therefore more likely to degenerate (18). However, after repeated rounds of degeneration and regeneration, the dystrophin competent satellite cells are eventually recruited and newly formed fiber segments stabilized. This is one of the mechanisms which leads to the "normalization" of skeletal muscle of DMD carriers, that is, to a progressive increase in the total number of dystrophinpositive myofibers as carriers age (17). Therefore, we have also attempted to evaluate whether a similar process is active in dystrophic mouse skeletal muscle after in vivo retroviral-mediated transduction of the dystrophin minigene.

\section{Methods}

Construction of the retroviral vector $p D y B I N$. To construct the vector pDyBIN [dystrophin Becker-type, IRES (internal ribosome entry site), Neo (neomycin phosphotransferase)], the vector pLNEPN (generous gift of Dr. A.D. Miller; reference 19) was digested with EcoRI and BstXI to release the insert containing purine nucleoside phosphorylase and Neo genes and leave the backbone free for subsequent cloning. A polylinker was inserted in the EcoRI/BstXI site. The encephalomyocarditis virus IRES element fused to the Neo gene (kind gift of Dr. B. McStay; reference 20) was inserted in the SnaBI/ PacI site of the polylinker by directional cloning. The resulting vector pLIN was digested with NotI and SalI, and the Becker-type 6.3-kb dystrophin cDNA obtained from pRSVDyB (21) was inserted by directional cloning to give the $9.8-\mathrm{kb}$ pDyBIN provirus. In $\mathrm{pDyBIN}$, the dystrophin minigene and the Neo gene are separated by an IRES element and are both transcribed from the viral long terminal repeats (LTRs).

$P C R$. The reaction was performed in $50 \mu \mathrm{l}$ final volume containing $500 \mathrm{ng}$ genomic DNA, $1 \times$ PCR buffer (Stratagene, Cambridge, United Kingdom), $8 \mathrm{mM} \mathrm{MgCl} 2,0.96 \mathrm{mM}$ dNTPs, $8 \mathrm{U}$ Taq polymerase (Stratagene), and $8 \mathrm{U}$ Taq extender (Stratagene). Cycling parameters were: $94^{\circ} \mathrm{C}, 3 \mathrm{~min}$ as a single denaturing cycle; $94^{\circ} \mathrm{C}, 1 \mathrm{~min}$; $55^{\circ} \mathrm{C}, 50 \mathrm{~s} ; 72^{\circ} \mathrm{C}, 7$ min over 30 cycles. Primer sequences were as follows: forward $\psi$ : 5'-CCTTCTGCTCTGCAGAATGGC-3', which is complementary to a region of the packaging signal of DyBIN vector and reverse Neo: 5'-CCCGCTTCAGTGACAACGTCG-3' which is complementary to the Neo gene in the DyBIN vector (19). The PCR product band has an expected length of $7.5 \mathrm{~kb}$, corresponding to almost the entire DyBIN provirus with the exclusion of the LTRs.

Growth and maintenance of cells. Mouse cell lines were grown in DME (Sigma Chemical Co., Dorset, United Kingdom) supplemented with $10 \%$ FCS (Sigma Chemical Co.) and $2 \mathrm{mM} \mathrm{L-glutamine}$ at $37^{\circ} \mathrm{C}$ in an atmosphere containing $8 \% \mathrm{CO}_{2}$. Primary mouse muscle cultures were grown on laminin-coated dishes in DME supplemented with $20 \%$ FCS. Human muscle cultures were grown on merosin-coated dishes in Ham-F10 media (Sigma Chemical Co.) supplemented with $2 \mathrm{mM}$ L-glutamine, $20 \%$ FCS, $0.1 \mathrm{mg} / \mathrm{ml}$ insulin, $1 \mu \mathrm{M}$ dexamethasone, 0.1 $\mu \mathrm{g} / \mathrm{ml}$ epidermal growth factor, and $0.1 \mu \mathrm{g} / \mathrm{ml}$ fibroblast growth factor (all purchased from Sigma Chemical Co.) at $37^{\circ} \mathrm{C}$ in an atmosphere containing $5 \% \mathrm{CO}_{2}$.

Construction of amphotropic and ecotropic retroviral producer cell clones for dystrophin gene transfer. The amphotropic packaging cells GP+Am12 (22) were seeded in 60 -mm dishes $\left(1.5 \times 10^{4}\right.$ cells $\left./ \mathrm{cm}^{2}\right)$ and transfected $24 \mathrm{~h}$ later with pDyBIN plasmid using lipofectaminemediated DNA complexes as previously described (23). After $72 \mathrm{~h}$ cells were trypsinized and dispersed at various densities into 24-well tissue culture dishes in the presence of $500 \mu \mathrm{g} / \mathrm{ml} \mathrm{G} 418$ to provide dilution cloning conditions. 15 G418-resistant clones were isolated and expanded. Genomic DNA was extracted from these clones and analyzed by PCR with $\psi /$ Neo primer set. Of 15 clones examined, 9 were found to carry the unrearranged DyBIN vector and were then checked for minidystrophin expression by Western blot. The four dystrophin-positive clones were expanded and viral-containing supernatants were collected and used to infect NIH $3 \mathrm{~T} 3$ fibroblasts. Infected fibroblasts were selected in $500 \mu \mathrm{g} / \mathrm{ml} \mathrm{G} 418$ for $12 \mathrm{~d}$ and viral titers counted. To test the stability of the viral vector, individual polyclonal populations of NIH 3T3 fibroblast infected with supernatants from the DyBIN clones were selected in G418, expanded, and subjected to Western blot and PCR analysis. Polyclonal populations of NIH 3 T3 cells infected with virus produced from DyBIN clones 2 and 7 were expressing the minidystrophin and were carrying the intact DyBIN provirus. No helper virus was found in the DyBIN clones 2 and 7 as checked by mobilization assay ( $2 \mathrm{wk}$; reference 24). DyBIN clone 7 was found to have the highest titer $\left(5 \times 10^{4} \mathrm{cfu} / \mathrm{ml}\right)$. To prepare a high titer ecotropic producer cell clone, AmpliGPE packaging cells $(25)$ were seeded in $3-\mathrm{cm}^{2}$ wells $\left(6 \times 10^{4}\right.$ cells $\left./ \mathrm{cm}^{2}\right)$ and infected with $1 \mathrm{ml}$ of retroviral-containing supernatants from DyBIN 7 amphotropic producer cell clone. The procedure was repeated six times every 3 or $4 \mathrm{~d}$ and then the infected AmpliGPE cultures were cloned by limiting dilution. 23 ecotropic clones were isolated and analyzed by PCR and Western blot as previously described for the amphotropic clones. Ecotropic clones which were carrying the intact DyBIN vector and were expressing the $229-\mathrm{kD}$ minidystrophin (clone names: AmpliDyBIN 1, 10, 20, and 21, respectively) were then screened for titer of released virus. Clone AmpliDyBIN 1 had a titer of $2 \times 10^{5}$ $\mathrm{cfu} / \mathrm{ml}$ and was found to be helper virus-free by mobilization assay.

Preparation of retroviral producer cells for transplantation. About $10^{6}$ AmpliDyBIN 1 producer cells were seeded in 100-mm tissue culture dishes in the presence of $1-1.5 \mu \mathrm{g} / \mathrm{ml}$ mitomycin C (Sigma Chemical Co.) for $16 \mathrm{~h}$. Cells were then washed twice in PBS + $0.02 \%$ EDTA (very briefly to avoid detachment), trypsinized, resuspended in a small volume (generally $10-50 \mu \mathrm{l}$ ) of Hepes-buffered DME, and held in ice until used.

Dissociation of mouse and human muscle tissue and infection of primary myoblasts. Mouse muscle tissue was dissociated as previously described (26). All human samples were collected for diagnostic purposes after informed consent (courtesy of Department of Histopathology, UMDS Guy's Hospital, London, United Kingdom). Muscle samples were washed several times in PBS, transferred in HamF10 media, and then minced into $<5$-mm diameter pieces using fine scissors. Muscle pieces were seeded into plastic tissue culture dishes to allow satellite cell spread. After 7-10 d, cultures were trypsinized, filtered through a $50 \mu \mathrm{m}$ sterile nylon filter, and plated onto merosincoated dishes ( $5 \mu \mathrm{g} / \mathrm{ml}$; Chemicon International Co., Temecula, CA). Viral-containing supernatants were added in the presence of $8 \mu \mathrm{g} / \mathrm{ml}$ polybrene when primary myoblasts reached $50-60 \%$ confluency. Human and mouse myoblasts were induced to differentiate to myotubes by changing the medium to DME supplemented with $5 \%$ heat-inactivated horse serum. Cultures were analyzed for immunocytochemistry and Western blot $10 \mathrm{~d}$ later.

Immunocytochemistry and immunohistochemistry. Monoclonal antibody (mAb) Dy8/6C5 against the carboxy terminus of dystrophin (residues 3668-3685) $(27,28)$ and mAb Ad1/20A6 against $\alpha$-sarcoglycan were a gift of Dr. L. Anderson (Newcastle General Hospital, United Kingdom). mAb MANDYS1 biotinylated against the rod domain of dystrophin was a gift of Drs. N.-T. Man and G. Morris (North East Wales Institute, United Kingdom) $(29,30)$. P6 is a rabbit polyclonal antibody against the carboxy-terminal repeat region of the rod domain of dystrophin (31). mAb D33 against desmin was purchased from Dako Ltd. (Bucks, United Kingdom). Rat mAb against the neu- 
ral cell adhesion molecule (N-CAM) H-28 was a gift of Dr. S. Moore (Guy's Hospital, London, United Kingdom) (32). Secondary antibodies were: biotinylated anti-mouse Ig and IgG (from sheep), biotinylated anti-rabbit IgG (from donkey) (Amersham International, Buckinghamshire, United Kingdom) and fluorescein-conjugated anti-rat IgG from goat (Sigma Chemical Co.). Streptavidin Texas red was purchased from Amersham. Immunocytochemical staining for dystrophin detection was performed as previously described (33). For immunohistochemistry, tissues were snap frozen in liquid $\mathrm{N}_{2}$-cooled isopentane. Cryostat sections were blocked in PBS containing $10 \%$ (vol:vol) FCS (in the case of P6 antibody) or 10\% FCS $+10 \%$ normal rabbit serum (in the case of mouse $\mathrm{mAb}$ ) for $30 \mathrm{~min}$ at room temperature. Primary antibody was then added for $30 \mathrm{~min}$. After three washing steps of $10 \mathrm{~min}$ each, biotinylated secondary antibody was added for $30 \mathrm{~min}$ and samples were washed as before. For immunofluorescence analysis, samples were incubated 30 minutes with streptavidin Texas red, washed three times in PBS, and mounted. For light microscopy analysis, samples were incubated with alkaline phosphatase or horseradish peroxidase-conjugated ABC solution (Dako), washed three times, and finally incubated in Sigma FAST BCIP/NTB (5-bromo-4-chloro-indolyl phosphate and nitro blue tetrazolium) or Sigma FAST DAB tablets (3,3'-diaminobenzidine tetrahydrochloride) solutions prepared according to the manufacturer's instructions at $4^{\circ} \mathrm{C}$ for $1-3 \mathrm{~min}$. Sections were then washed in water, dehydrated in methanol, and mounted.

SDS-PAGE and Western blot. Cell cultures (100-mm dishes) were rinsed twice in PBS and then collected in 150-200 $\mu$ l sample buffer ( $75 \mathrm{mM}$ Tris, $\mathrm{pH} 6.8,10 \%$ SDS, $0.1 \%$ bromophenol blue, $20 \%$ glycerol, $100 \mathrm{mM}$ DTT, $20 \mu \mathrm{g} / \mathrm{ml}$ PMSF, $0.06 \mathrm{mg} / \mathrm{ml}$ antipain, $0.01 \mathrm{mg} / \mathrm{ml}$ aprotinin, $0.5 \mu \mathrm{g} / \mathrm{ml}$ leupeptin hemisulphate, $0.2 \mathrm{mg} / \mathrm{ml}$ EDTA, all purchased from Sigma Chemical Co.) passed through a 25 gauge needle to fragment the DNA and heated at $100^{\circ} \mathrm{C}$ for $5 \mathrm{~min}$. Samples were loaded on a $7.5 \%$ polyacrylamide gel and Western blotting was then performed as previously described (13). For desmin detection, after the transfer and blocking steps, the membrane was incubated for $2 \mathrm{~h}$ at room temperature with vigorous shaking with a mixture of antidesmin mAb D33 (diluted 1:50) and antidystrophin mAb Dy8/6C5 (diluted 1:20).

Animals. A colony of C57BL/10mdx $(m d x)$ mice and Nude/mdx mice was kindly provided by Prof. T. Partridge (Hammersmith Hospital, London, United Kingdom). C57BL/10 mice were purchased from Harlan Olac (Bicester Oxon, United Kingdom).

Anesthesia. Mice were anesthetized by intraperitoneal injection of a mixture of the anesthetics Hypnorm (fentanyl-fluonasone; Jansen Pharmaceutica, High Wycombe, Buckinghamshire, United Kingdom) and Hypnovel (midazolam; Roche Laboratories, Nutley, NJ) in sterile distilled water in the ratio 1:1:2 according to Flecknell (34). 5-7 $\mathrm{ml}$ of freshly prepared mixture was injected intraperitoneally per kilogram of body weight using a gauge 27 hypodermic needle.

Muscle degeneration and infection. Tibialis anterior (TA) muscles were degenerated by injection of $30-50 \mu \mathrm{l} 1.2 \% \mathrm{BaCl}_{2}$ in normal saline (35). Approximately 30-50 $\mu$ l of producer cell suspension was injected in a single shot 4-6 h after muscle degeneration.

Immunosuppression of animals. The immunosuppressive drug FK506 (Fujisawa Pharmaceuticals, Osaka, Japan) was freshly diluted at a final concentration of $1 \mathrm{mg} / \mathrm{ml}$, and injected intraperitoneally $(2.5$ $\mathrm{mg} / \mathrm{kg}$ per d) for $6 \mathrm{~d}$, starting $1 \mathrm{~d}$ before cell implantation.

Statistical analysis. Statistical significance was assessed by Student's $t$ test. $P<0.05$ was taken as significant. Data are expressed as means \pm SD.

\section{Results}

Infection of mouse and human myoblasts in vitro. The amphotropic DyBIN 7 and the ecotropic AmpliDyBIN 1 producer
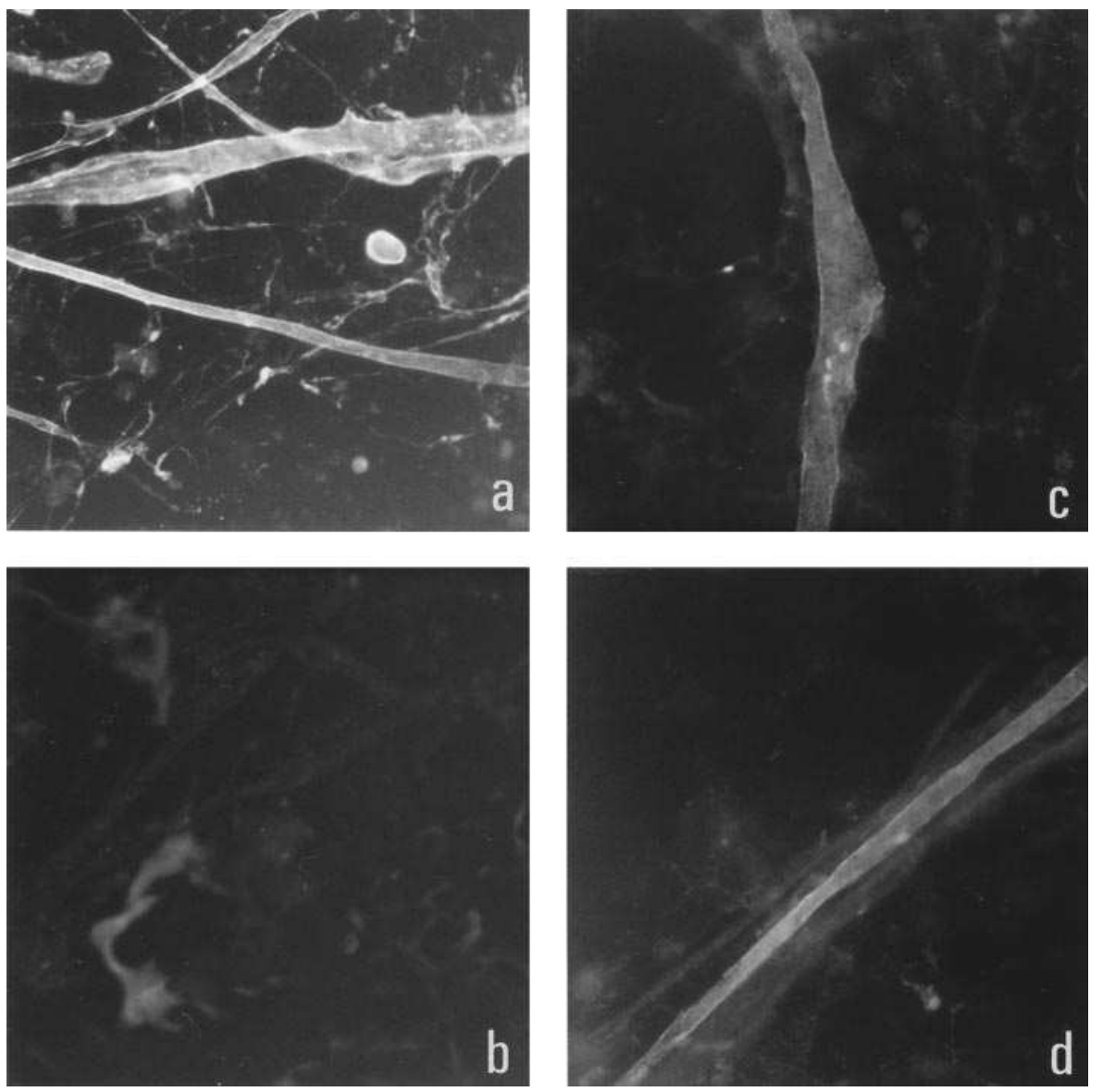

Figure 1. Immunocytochemical staining of human and mouse myotubes with Dy8/6C5 antidystrophin antibody. Primary cultures from $m d x$ and C57BL/10 mouse or DMD patient were grown in laminin or merosincoated dishes. Primary cultures from C57BL/10 mouse ( $a$ ) and $m d x$ mouse (b) were induced to differentiate to myotubes by changing the medium to $5 \%$ horse serum. Fresh amphotropic virus $(500 \mu \mathrm{l})$ was used to infect DMD myoblasts $(c)$ and fresh ecotropic virus $(300 \mu \mathrm{l})$ was used to infect $m d x$ mouse myoblasts $(d)$ which were then induced to differentiate as above $(\times 200)$. 


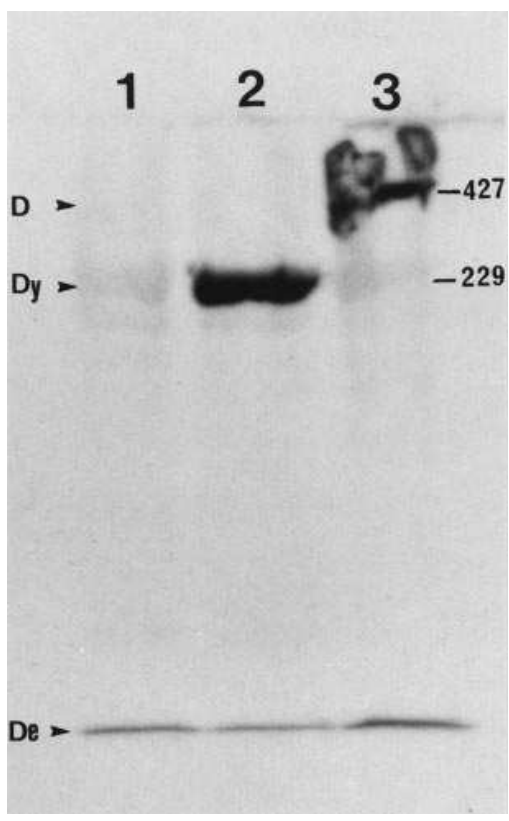

Figure 2. Dystrophin expression in human myotube cultures. DMD cultures (lane 1), DMD cultures infected with amphotropic virus (lane 2), or normal human cultures (lane 3 ) were collected in sample buffer, loaded on a $7.5 \%$ polyacrylamide gel and then analyzed by Western blot. Primary antibodies were antidystrophin Dy8/ $6 \mathrm{C} 5$ and antidesmin D33. Right margin indicates $M_{\mathrm{r}} \times 10^{-3} . D$, dystrophin (full length); $D y$, dystrophin (minigene); $D e$, desmin

cell clones were tested for the ability to infect in vitro human and mouse myoblasts, respectively, and to express the minidystrophin. After infection, mouse or human myoblasts were allowed to differentiate into myotubes and were immunocytochemically stained for dystrophin (Fig. 1). No staining was observed in uninfected mdx and DMD cultures. In infected cultures before fusion only very rarely was specific dystrophin staining observed in mononucleated cells. About a week after myoblasts differentiated into myotubes, dystrophin was detected at the sub-sarcolemmal region. In a few myotubes, patches of cytoplasmic staining were also observed. Confocal microscopy confirmed that dystrophin was mainly localized at the myotube surface membrane. Infected human DMD myoblasts were also selected in G418 for $1 \mathrm{wk}$ and analyzed by Western blot either before or after fusion into myotubes. The minidystrophin was expressed in infected human myoblasts and myotubes, consistent with the fact that the viral LTR is not developmentally regulated (not shown). In transduced DMD myotubes minidystrophin appeared to be expressed at levels comparable to endogenous dystrophin (Fig. 2).
Transplantation of retroviral producer cells for dystrophin gene transfer. AmpliDyBIN 1 producer cells were mitotically inactivated by treatment with mitomycin $\mathrm{C}$, the left TA muscles of 18 6-wk-old nude $/ m d x$ mice were artificially degenerated and cells were injected 4-6 h after muscle degeneration. Treated animals were divided in two groups, depending on the number of transplanted cells: 12 animals received $2.5 \times 10^{5}$ producer cells and 6 animals received $3 \times 10^{6}$ cells. Nude $/ m d x$ mice which received the lower dose of cells were killed at $6 \mathrm{wk}$ (4 mice), $12 \mathrm{wk}$ (4 mice), and $24 \mathrm{wk}$ (4 mice) after producer cell transplantation. Nude $/ m d x$ mice which received $3 \times 10^{6}$ cells were all killed $6 \mathrm{wk}$ after cell transplantation. At all time points hematoxylin and eosin staining of treated TA muscles showed no morphological differences compared to sham injected $m d x$ mouse TA muscles. As shown in Fig. 3 and Table I, large numbers of minidystrophin expressing $\left(\mathrm{dys}^{+}\right)$fibers were counted in all treated muscles (5.5-18\% of total muscle fibers). Immunostaining of serial sections with mAb MANDYS1 showed only very few $(20 \pm 10) d y s^{+}$fibers, consistent with the pattern observed with P6 antibody in control $m d x$ mice (not shown). This indicated that the vast majority of $d y s^{+}$fibers detected with P6 antibody were expressing the Becker-type human dystrophin cDNA, for the region recognized by $\mathrm{mAb}$ MANDYS1 is deleted in the $229-\mathrm{kD}$ Becker minidystrophin $(8,29)$. With regard to the time course experiment, no significant difference was found in the number of $d y s^{+}$fibers at 6,12 , and $24 \mathrm{wk}$ after producer cell transplantation (Student's $t$ test, $P>0.5)$. However, a statistically significant twofold increase was found between the group of mice injected with $3 \times 10^{6}$ producer cells and the group injected with $2.5 \times 10^{5}$ producer cells (Student's $t$ test, $P<0.02$ ).

Producer cells can be transplanted in immunocompetent mice under short-term immunosuppression. To evaluate the feasibility of this approach in immunocompetent mice, a shortterm immunosuppression regimen was designed to avoid the rapid rejection of the implanted cells which was observed in a previous study (7). The immunosuppressive drug FK506 (tacrolimus) was chosen, for it has been successfully used to control rejection in myoblast transplantation experiments (36). The left TA muscle of 145 -wk-old immunocompetent $m d x$ mice was degenerated as before and injected with $10^{6} \mathrm{Am}$ pliDyBIN 1 retroviral producer cells 4-6 h later. Seven mice received mitomycin C-treated cells and the other seven received untreated, mitotically active cells. All mice were killed after 3 wk.

Table I. Number of dys ${ }^{+}$Fibers After Transplantation of AmpliDyBIN 1 Retroviral Producer Cells

\begin{tabular}{|c|c|c|c|c|c|}
\hline Mouse strain & $\begin{array}{l}\text { Weeks after } \\
\text { injection }\end{array}$ & No. of $d y s^{+}$fibers & Mean \pm SD & Percent range & $\begin{array}{l}\text { Percentage of clustered } d y s^{+} \\
\quad \text { fibers }(\text { mean } \pm \text { SD) }\end{array}$ \\
\hline Nude $/ m d x\left(2.5 \times 10^{5}\right.$ cells $)$ & 6 & $170 / 136 / 100 / 106$ & $128 \pm 28$ & $6-9.5$ & $2.5 \pm 0.5$ \\
\hline Nude $/ m d x\left(2.5 \times 10^{5}\right.$ cells $)$ & 12 & $305 / 92 / 146 / 100$ & $160 \pm 86$ & $5.5-17$ & $16.3 \pm 11$ \\
\hline Nude $/ m d x\left(2.5 \times 10^{5}\right.$ cells $)$ & 24 & $185 / 78 / 70$ & $111 \pm 52$ & 4-10.2 & $12.5 \pm 4$ \\
\hline Nude $/ m d x\left(3 \times 10^{6}\right.$ cells $)$ & 6 & $325 / 270 / 230 / 185 / 160 / 132$ & $217 \pm 66$ & $7.3-18$ & ND \\
\hline$m d x\left(10^{6}\right.$ cells $)$ & 3 & $164 / 144 / 107 / 96 / 90 / 81 / 83$ & $109 \pm 30$ & $4.6-9.1$ & ND \\
\hline
\end{tabular}

AmpliDyBIN 1 producer cells were treated with mitomycin $\mathrm{C}$ and injected into TA muscles which were degenerated 4-6 h before using $\mathrm{BaCl}$. The number of cells transplanted is indicated in brackets. Transduced $d y s^{+}$fibers were counted on sections immunostained with antidystrophin P6 polyclonal antibody. Data points from different animals are separated by slashes. A TA muscle of an $m d x$ mouse is composed of $1800 \pm 250$ myofibers. $N D$, not done. 

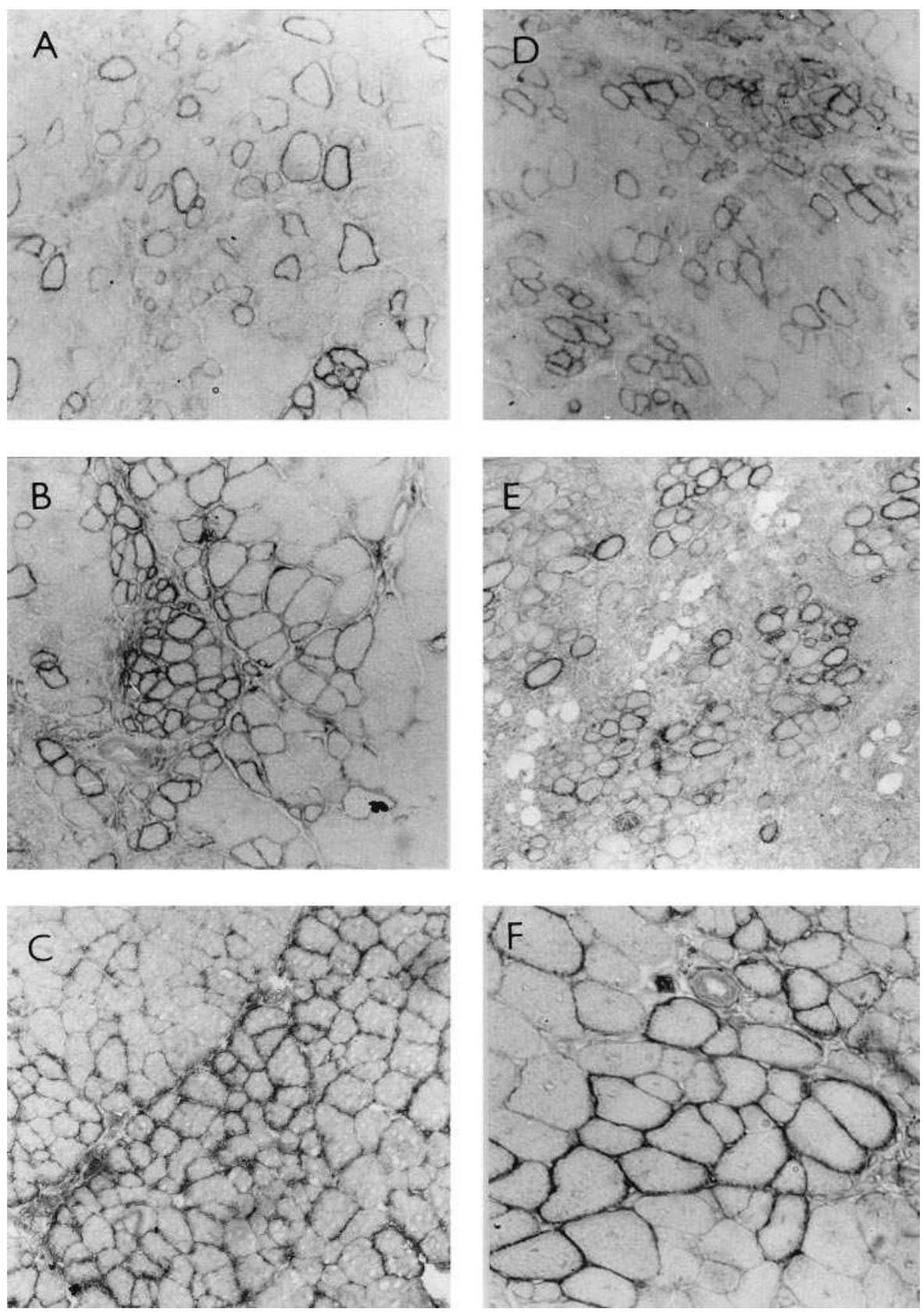

Figure 3. Immunohistochemistry for dystrophin detection in $m d x$ mice muscle sections. TA muscles were degenerated with $\mathrm{BaCl}_{2}$ and 4-6 $\mathrm{h}$ later retroviral producer cells were transplanted. Nude/mdx mice received $2.5 \times 10^{5}(A$ and $C, \times 200 ; F$, $\times 400)$ or $3 \times 10^{6}(B, \times 200)$ mitomycin C-treated AmpliDyBIN 1 producer cells and killed after 6 wk $(A, B), 12$ wk $(C)$ or 24 wk $(F)$. Temporarily immunosuppressed $m d x$ mice received $10^{6}$ mitomycin C-treated $(D, \times 200)$ or untreated $(E, \times 200)$ AmpliDyBIN 1 producer cells and were killed after $3 \mathrm{wk}$.

The efficiency of dystrophin gene transfer in temporarily immune-suppressed $m d x$ mice which received mitomycin $\mathrm{C}$-treated cells was as good as that obtained in nude/ $m d x$ mice (Fig. $3 \mathrm{D}$ and Table I). Muscle morphology showed no abnormality compared to $m d x$ controls. However, substantial inflammatory infiltration and fibrosis were apparent in the TA muscles which received implants of nonmitomycin $\mathrm{C}$-treated cells (Fig. $3 E$ ) and the number of $d y s^{+}$fibers was not counted. This suggested that an immunoreaction occurred after FK506 withdrawal, probably as a consequence of producer cell proliferation during the period of immunosuppression.

Reexpression of $\alpha$-sarcoglycan in transduced fibers. Dystrophin is associated at the sarcolemma with a complex of proteins and glycoproteins (namely $\alpha$ - and $\beta$-dystroglycans, $\alpha-, \beta-$, and $\gamma$-sarcoglycans; reference 37 ). The correct assembly of dystrophin with the associated protein complex (DAG) ap- pears to be essential to prevent muscular dystrophy $(38,39)$. Serial sections of the TA muscles injected with AmpliDyBIN 1 producer cells 6 and $12 \mathrm{wk}$ earlier were immunostained for $\alpha$-sarcoglycan detection. As shown in Fig. $4, \sim 65 \%$ transduced $d y s^{+}$fibers were also positive for $\alpha$-sarcoglycan, suggesting that in many cases the DAG complex was at least in part restored at the sarcolemma. Immunostaining of serial sections with $\mathrm{mAb}$ MANDYS1 showed that the fibers staining positively for $\alpha$-sarcoglycan were not revertants. More than $75 \%$ $\alpha$-sarcoglycan positive fibers were still centrally nucleated 12 wk after gene transfer.

Retrovirally transduced skeletal muscle undergoes active remodeling. To investigate whether satellite cells could be infected in vivo with the retroviral vector carrying the dystrophin minigene, the TA muscles of four 9-wk-old nude/ $m d x$ mice were degenerated with $\mathrm{BaCl}_{2}$ and injected $4 \mathrm{~h}$ later with $5 \times$ 

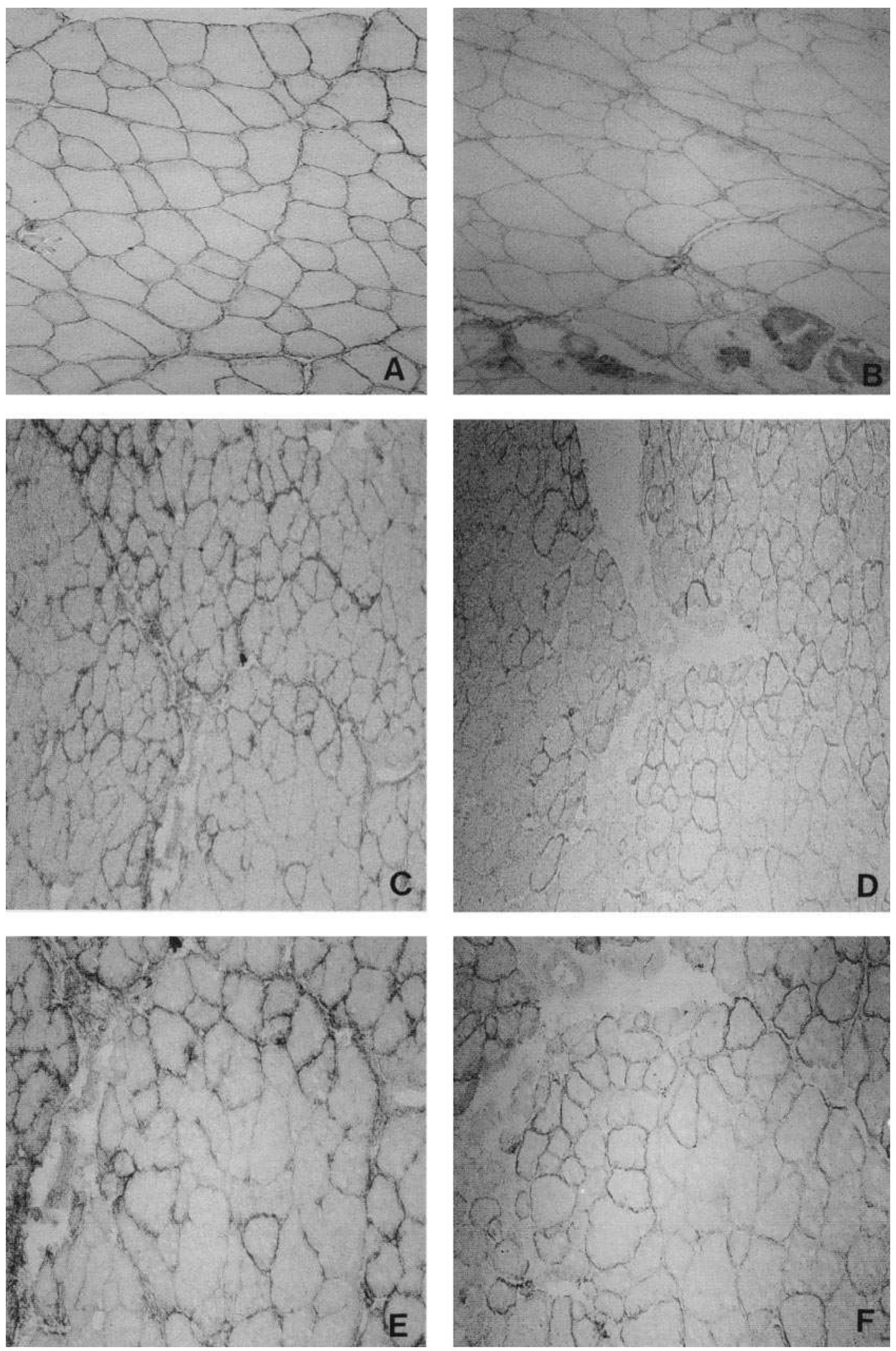

Figure 4. Immunohistochemistry for dystrophin and $\alpha$-sarcoglycan detection. Muscle sections of C57BL/10 mouse ( $A$ $\times 200)$ and $m d x$ mouse $(B, \times 200)$ were immunostained with Ad1/20A6 anti $\alpha$-sarcoglycan antibody. Sections $250 \mu \mathrm{m}$ apart of the same nude/ $m d x$ mouse muscle transplanted 12 wk before with AmpliDyBIN 1 producer cells were immunostained for detection of dystrophin $(C, \times 200 ; E, \times 400)$ and $\alpha$-sarcoglycan $(D$, $\times 200 ; F, \times 400$ ).

$10^{5}$ mitomycin C-treated producer cells. Mice were killed 3 mo later. Treated TA muscles were dissociated to release mononucleated satellite cells. Primary cultures were selected in media containing $200 \mu \mathrm{g} / \mathrm{ml} \mathrm{G} 418$ for $12 \mathrm{~d}$. At the end of the selection procedure, cells obtained from untreated muscles all died whereas G418-resistant populations were clearly obtained from the transplanted TA muscles. To exclude the presence of replication competent virus or active producer cells in the tissue culture samples, culture media were collected from confluent (G418-resistant) primary cells and used to infect NIH 3T3 

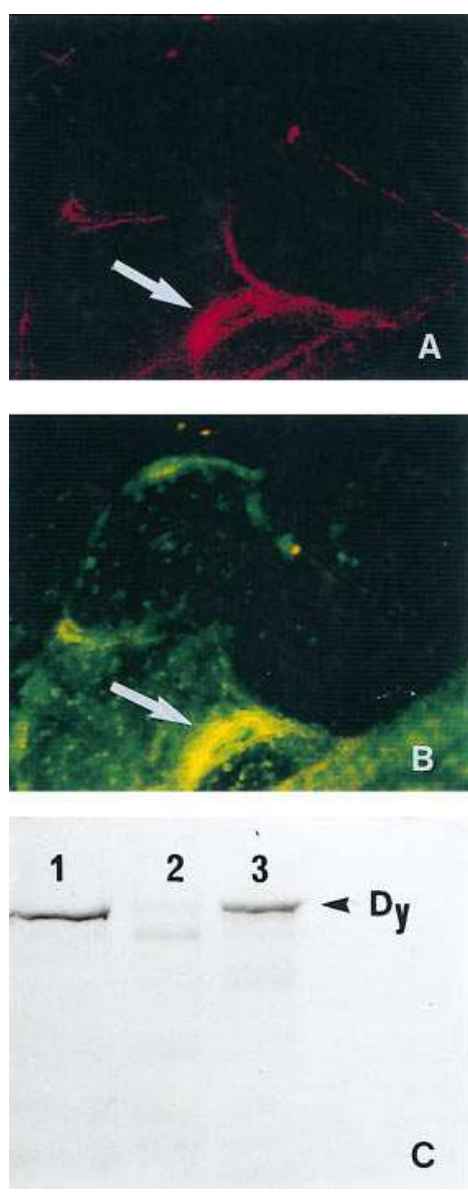

Figure 5. Identification of probable satellite cells transduced in vivo with DyBIN vector. Muscle sections of nude/mdx mice transplanted with AmpliDyBIN producer cells were doubly immunolabeled with antidystrophin antibody $(A)$ or antiN-CAM antibody $(B)$; $\times 400$. Arrows indicate satellite cells. Some of the muscles treated 3 mo earlier were also dissociated, primary cultures selected in G418 for $12 \mathrm{~d}$, and subjected to Western blot for dystrophin detection $(C$, lane 1$)$. Primary cultures from untreated $m d x$ mice $(C$, lane 2) and AmpliDyBIN 1 producer cells $(C$, lane 3) were also analyzed by Western blot. $D y, 229$ $\mathrm{kD}$ minidystrophin.

fibroblasts. No G418-resistant NIH 3 T3 cell population was detected after 2 wk of culture. The primary cultures were also analyzed by Western blotting. As shown in Fig. 5, a $d y s$ band was clearly detectable. Immunostains of tissue sections demonstrated the presence of $d y s^{+}$mononucleated cells positioned at the periphery of muscle fibers, some of which were also positive for N-CAM, which is a marker of myogenic cells $(40,41)$ (Fig. 5). Thus, these cells were tentatively identified as satellite cells.

Taken together, these data suggested that satellite cells had been infected in vivo by the DyBIN virus. Moreover, TA muscles of nude/ $m d x$ mice transplanted with producer cells 3 and 6 mo earlier showed the presence of large clusters of $d y s^{+}$fibers (Fig. 3) which were never detected at earlier time points, not even in the mice transplanted with $3 \times 10^{6}$ producer cells. To quantitate this observation, the percentage of $d y s^{+}$fibers which were completely surrounded by other $d y s^{+}$fibers at each time point was counted. On average, one myofiber is surrounded by four to six fibers. As shown in Table I, the percentage of clustered $d_{y s}{ }^{+}$fibers increased fivefold 12 and 24 wk after dystrophin gene transfer compared to $6 \mathrm{wk}$ and the difference was statistically significant (Student's $t$ test: $6 \mathrm{wk}$ versus $12 \mathrm{wk}$, $P<0.05 ; 6$ wk versus 24 wk; $P<0.005$ ). To evaluate whether the clustering effect was due to de novo fusion of transduced satellite cells, sections of treated TA muscles of each time point $(6,12$, and 24 wk after transplantation) were double immunolabeled with antibodies against dystrophin and N-CAM, which is specifically expressed in regenerating myofibers $(32,40,41)$.
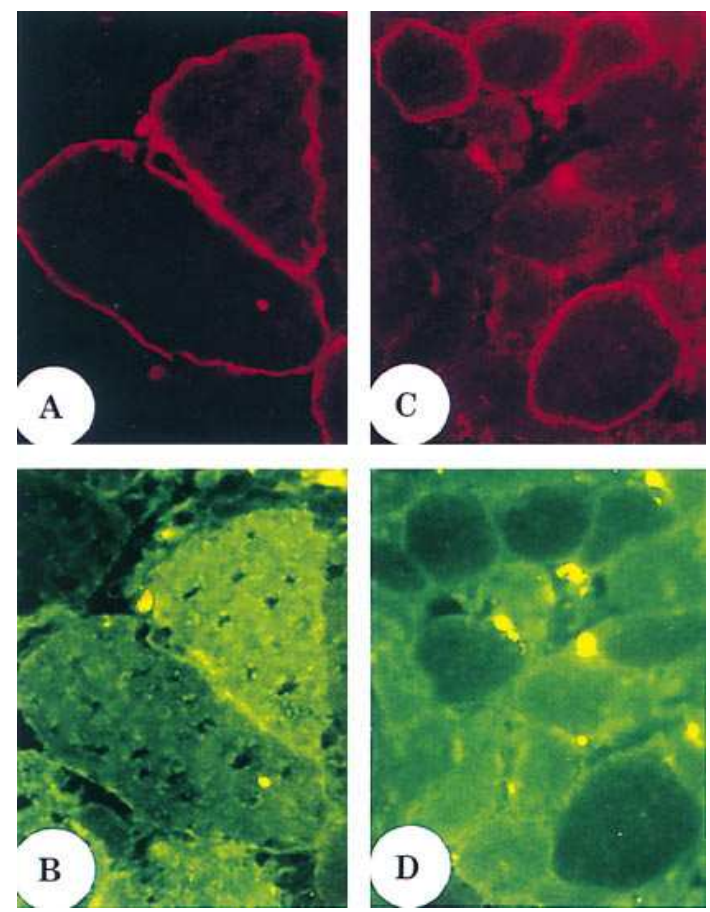

Figure 6. Double immunolabeling for dystrophin and N-CAM. TA muscles of Nude $/ m d x$ mice received $2.5 \times 10^{5} \mathrm{AmpliDyBIN}$ producer cells. Double immunolabeling was performed on muscle sections of mice killed after 6 wk ( $A$, dystrophin; $B, \mathrm{~N}-\mathrm{CAM})$ and $24 \mathrm{wk}(C$, dystrophin; $D, \mathrm{~N}-\mathrm{CAM}) ; \times 400$.

Groups of $d y s^{+}$and N-CAM ${ }^{-}$fibers were frequently found adjacent to $d y s^{+}$and $\mathrm{N}-\mathrm{CAM}^{+}$fibers in TA muscles analyzed 6 wk after transplantation but not in muscles analyzed at later time points (Fig. 6). As shown in Fig. 7, the percentage of $\mathrm{N}-C A M^{+}$fibers in the $d y s^{+}$fiber population decreased threefold in treated TA muscles of mice killed 12 and 24 wk after cell transplantation compared to the mice killed after $6 \mathrm{wk}$ and the difference was statistically significant (Student's $t$ test: $6 \mathrm{wk}$ versus $12 \mathrm{wk}, P<0.0001 ; 6 \mathrm{wk}$ versus $24 \mathrm{wk}, P<0.0001)$. The percentage of $\mathrm{N}_{-} \mathrm{CAM}^{+}$and $d y s^{-}$fibers did not decrease in older animals (Fig. 7).

\section{Discussion}

The procedure based on the transplantation of retroviral producer cells into regenerating skeletal muscle proved to be a successful approach for dystrophin gene transfer in $m d x$ mouse muscle. The quantity of producer cells transplanted into regenerating muscle appeared to be an important factor, since a twofold difference in the number of $d y s^{+}$fibers was observed between the groups of mice injected with $2.5 \times 10^{5}$ and $3 \times 10^{6}$ cells. This should not be a limiting factor since injection of up to $3 \times 10^{6}$ cells did not significantly alter the morphology of treated muscles and producer cell lines can easily be grown in large quantities. The transplantation procedure also proved feasible in immunocompetent $m d x$ mice under short-term immunosuppression with the drug FK506. Thus, an appropriate temporary immunosuppressive regimen and a well-designed protocol for mitotic-inactivation of producer cells may result in the ability to control the time and progression of gene transfer 


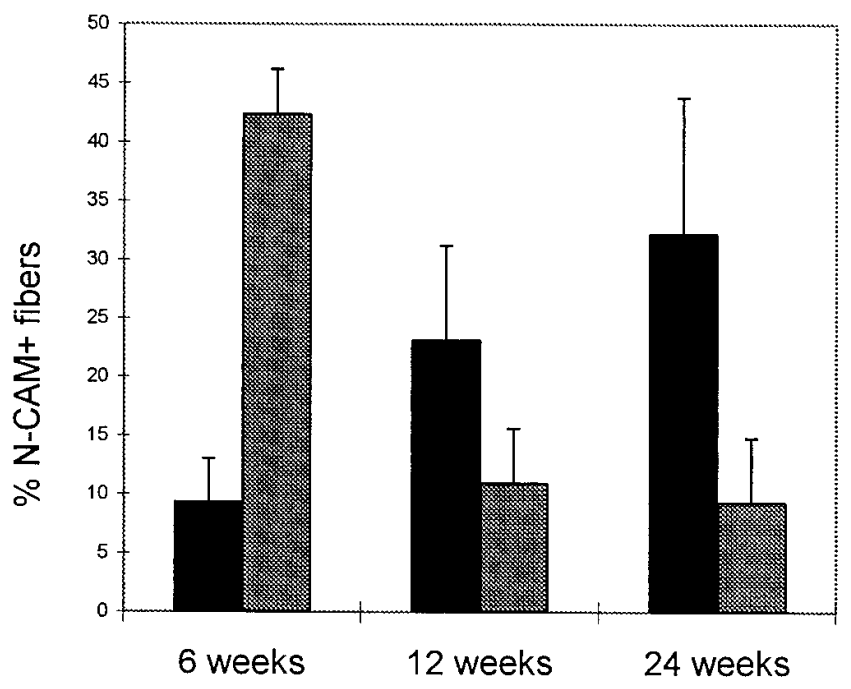

Figure 7. Histograms representing the percentage of $\mathrm{N}_{-} \mathrm{CAM}^{+}$fibers in the $d y s^{-}$fiber population at different time points (black bars) or the percentage of $\mathrm{N}_{-} \mathrm{CAM}^{+}$fibers in the $d y s^{+}$fiber population at different time points (gray bars). Nude/mdx mice were transplanted with AmpliDyBIN 1 producer cells and muscle sections were doubly immunolabeled for dystrophin and N-CAM. Positive fibers were counted in randomly chosen sections. Data are shown as mean \pm SD. The number of $\mathrm{N}^{-\mathrm{CAM}^{+}}$fibers in the $d y s^{+}$fiber population at the $6 \mathrm{wk}$ time point is significantly different compared to 12 and $24 \mathrm{wk}$ time points (Student's $t$ test: 6 wk versus $12 \mathrm{wk}, P<0.0001 ; 6 \mathrm{wk}$ versus $24 \mathrm{wk}, P<0.0001)$.

in vivo. Immunocompetent mice were all killed 3 wk after gene transfer and no later time points were analyzed, since a cDNA encoding for the human dystrophin was used which might have induced an immunoresponse in mice in the long-term.

An important limiting factor for retroviral-mediated gene therapy is the extent of satellite cell proliferation in vivo while gene transfer is ongoing and artificial degeneration of skeletal muscle does not appear a feasible option in DMD patients. Furthermore, it should be noted that the heart which is affected in DMD patients is refractory to gene transfer by currently available retroviral vectors. Myocardium does not possess satellite cells and myocardiocytes lose their ability to divide early in development (42). The design of new types of retroviral vectors (43) may allow in vivo gene transfer in nondividing cells in the future and, perhaps, clinical application of gene transfer via transplantation of producer cells, although safety issues will need careful consideration.

A time course analysis of dystrophin and N-CAM expression in transplanted nude/ $m d x$ mice showed that treated muscles underwent active myofiber remodeling. Evidence was obtained, both in this study and in previous experiments using the reporter gene Lac-Z (7), that a proportion of satellite cells could be infected in vivo by the retroviral vector and survive as muscle precursor cells. We hypothesize that the observed muscle remodeling was a consequence of the degeneration of $d y s^{-}$ fibers and subsequent activation, proliferation, and fusion of $d y s^{+}$muscle stem cells transduced in vivo. Indeed, double immunolabeling showed the presence of many $d y s^{+}$and $\mathrm{N}_{-} \mathrm{CAM}^{+}$ fibers, especially in the younger mice. Such fibers were likely to derive from new spontaneous regeneration, since they were found 6,12 , and 24 wk after $\mathrm{BaCl}_{2}$ injection and $\mathrm{N}-\mathrm{CAM}$ is rapidly downregulated after regeneration is completed (40). Taken together, the data presented here suggest the presence in transduced $m d x$ mouse muscle of a process similar to genetic normalization which occurs in DMD carriers and leads to the formation of large clusters of $d y s^{+}$fibers with time (17). They also suggest the existence of some type of threshold effect. Extensive remodeling may not take place if the number of satellite cells initially infected is too low. The existence of a threshold effect leading to the repopulation of an organ by retrovirally transduced cells has already been shown in the liver (44) and may be a more general phenomenon of retroviralmediated gene therapy. Further investigations in the $m d x$ and $x c m d$ animal models are needed to evaluate to what extent such a phenomenon is active in skeletal muscle. An increase of clustered $d y s^{+}$fibers was found in all older animals. However, the total number of $d y s^{+}$fibers was not significantly different at different time points, suggesting also that a proportion of $d y s^{+}$fibers was being lost.

The expression of the Becker-type minidystrophin resulted also in reexpression of $\alpha$-sarcoglycan. This suggested that, in many cases, dystrophin reexpression is probably able by itself to stabilize the DAG complex in adult dystrophic muscle, in which alterations in the extracellular matrix are presumably present. This observation is consistent with a previous study in transgenic $m d x$ mice expressing dystrophin with a chimeric phenotype in skeletal muscle (45). Furthermore, the percentage of $\mathrm{N}_{-} \mathrm{CAM}^{+}$fibers in the $d y s^{+}$fiber population decreased in treated older animals, whereas the total number of N-CAM ${ }^{+}$ fibers did not. This suggested that minidystrophin expression was exerting a protective effect. However, most $d y s^{+}$fibers remained centrally nucleated even in the long-term and not all $d y s^{+}$fibers were expressing $\alpha$-sarcoglycan at the sarcolemma. At present it is not clear whether this is due to the artificially induced muscle degeneration or to some inability of adult dystrophic muscle to recover completely, despite the expression of dystrophin.

The data presented here may have general consequences for gene therapy of DMD. It is plausible that focal infection of satellite cells in a few muscle sites by retroviral vectors could result in their selective recruitment and more widespread dystrophin expression in myofibers. The extent of such selective myofiber repopulation may depend on the efficiency of satellite cells transduction, their proliferation potential in vivo, and anatomical barriers. On the other hand, it appears that not all transduced $d_{y s} s^{+}$fibers are necessarily stabilized and that a proportion of these fibers may be lost with time. The extent of $d y s^{+}$fiber loss may depend on the initial efficiency of in vivo dystrophin gene transfer, the overall level of correction of the dystrophic phenotype, and consequent stabilization of individual muscles.

\section{Acknowledgments}

We thank Dr. Y. Takahara for providing AmpliGPE cells, Dr. S. Goff for providing GP+Am12 cells, Dr. L. Anderson and Dr. G. Morris for providing antibodies, and Mrs. K. Wells for advice and helpful discussion.

This work was supported by the Muscular Dystrophy Group of Great Britain and Northern Ireland, the Leopold Muller Trust, and the Medical Research Council. 


\section{References}

1. Hoffman, E.P., R.H. Brown, and L.M. Kunkel. 1987. Dystrophin: the protein product of the Duchenne muscular dystrophy locus. Cell. 51:919-928.

2. Emery, A.E.H. 1993. Duchenne Muscular Dystrophy (Second Edition). Oxford University Press, Oxford, United Kingdom. 182-189.

3. Bulfield, G., W.G. Siller, P.A.L. Wight, and K.J. Moore. 1984. X chromosome-linked muscular dystrophy $(m d x)$ in the mouse. Proc. Natl. Acad. Sci. USA. 81:1189-1192.

4. Cooper, B.J., N.J. Winand, H. Stedman, B.A. Valentine, E.P. Hoffman, L.M. Kunkel, M.-O. Scott, K.H. Fischbeck, J.N. Kornegay, R.J. Avery, et al. 1988. The homologue of the Duchenne locus is defective in X-linked muscular dystrophy of dogs. Nature (Lond.). 334:154-156.

5. Allbrook, D. 1981. Skeletal muscle regeneration. Muscle Nerve. 4:234-245.

6. Schultz, E., and K.M. McCormick. 1993. Cell biology of the satellite cell. In Molecular and Cell Biology of Muscular Dystrophy. T.E. Partridge, editor. Chapman \& Hall, London, United Kingdom.

7. Fassati, A., D.J. Wells, F.S. Walsh, and G. Dickson. 1996. Transplantation of retroviral producer cells for in vivo gene transfer into mouse skeletal muscle. Hum. Gene Ther. 7:595-602.

8. England, S.B., L.V.B. Nicholson, M.A. Johnson, S.M. Forrest, D.R. Love, E.E. Zubrzycka-Gaarn, D.E. Bulman, J.B. Harris, and K.E. Davies. 1990. Very mild muscular dystrophy associated with deletion of $46 \%$ of dystrophin. Nature (Lond.). 343:180-182.

9. Ragot, T., N. Vincent, P. Chafey, E. Vigne, H. Gilgenkrantz, D. Couton, J. Cartaud, P. Briand, J.C. Kaplan, M. Perricaudet, and A. Kahn. 1993. Efficient adenovirus-mediated transfer of a human mini-dystrophin gene to skeletal muscle of $m d x$ mice. Nature (Lond.). 361:647-650.

10. Vincent, N., T. Ragot, H. Gilgenkrantz, D. Couton, P. Chafey, A. Grégoire, P. Briand, J.-C. Kaplan, A. Kahn, and M. Perricaudet. 1993. Long-term correction of mouse dystrophic degeneration by adenovirus-mediated transfer of a minidystrophin gene. Nat. Genet. 5:130-134.

11. Cox, G.A., N.M. Cole, K. Matsumura, S.F. Phelps, S.D. Hauschka, K.P. Campbell, J.A. Faulkner, and J.S. Chamberlain. 1993. Overexpression of dystrophin in transgenic $m d x$ mice eliminates dystrophic symptoms without toxicity. Nature (Lond.). 364:725-729.

12. Wells, D.J., K.E. Wells, F.S. Walsh, K.E. Davies, G. Goldspink, D.R. Love, P. Chan-Thomas, M.G. Dunckley, T. Piper, and G. Dickson. 1992. Human dystrophin expression corrects the myopathic phenotype in transgenic $m d x$ mice. Hum. Mol. Genet. 1:35-40.

13. Wells, D.J., K.E. Wells, E.A. Asante, G. Turner, Y. Sunada, K.P. Campbell, F.S. Walsh, and G. Dickson. 1995. Expression of human full-length and minidystrophin in transgenic $m d x$ mice: implications for gene therapy of Duchenne muscular dystrophy. Hum. Mol. Genet. 4:1245-1250.

14. Phelps, S.F., M.A. Hauser, N.M. Cole, J.A. Rafael, J.A. Faulkner, and J.S. Chamberlain. 1995. Prevention of muscular dystrophy by full-length and internally truncated dystrophins. Hum. Mol. Genet. 4:1251-1258.

15. Dunckley, M.G., D.J. Wells, F.S. Walsh, and G. Dickson. 1993. Direct retroviral-mediated transfer of a dystrophin minigene into $m d x$ mouse muscle in vivo. Hum. Mol. Genet. 2:717-723.

16. Acsadi, G., H. Lochmuller, A. Jani, J. Huard, B. Massie, S. Prescott, M. Simoneau, B.J. Petrof, and G. Karpati. 1995. Dystrophin expression in muscles of $m d x$ mice after adenovirus-mediated in vivo gene transfer. Hum. Gene Ther. 1:129-140.

17. Pegoraro, E., R.N. Schimke, C. Garcia, H. Stern, M. Cadaldini, C. Angelini, E. Barbosa, J. Carroll, W.A. Marks, H.E. Neville, et al. 1995. Genetic and biochemical normalization in female carriers of Duchenne muscular dystrophy: evidence for failure of dystrophin production in dystrophin competent myonuclei. Neurology. 45:677-690.

18. Hoffman, E.P., K. Arahata, C. Minetti, E. Bonilla, and L.P. Rowland. 1992. Dystrophinopathy in isolated cases of myopathy in females. Neurology. 42:967-975.

19. Adam, M.A., N. Ramesh, A.D. Miller, and W.R.A. Osborne. 1991. Internal initiation of translation in retroviral vectors carrying picornavirus $5^{\prime}$ nontranslated regions. J. Virol. 65:4985-4990.

20. Palmer, T.D., A.D. Miller, R.H. Reeder, and B. McStay. 1993. Efficient expression of a protein coding gene under the control of an RNA polymerase I promoter. Nucleic Acids Res. 21:3451-3457.

21. Acsadi, G., G. Dickson, D.R. Love, A. Jani, F.S. Walsh, A. Gurusinghe, J.A. Wolff, and K.E. Davies. 1991. Human dystrophin expression in $m d x$ mice after intramuscular injection of DNA constructs. Nature (Lond.). 352:815-818.

22. Markowitz, D., S. Goff, and A. Bank. 1988. Construction and use of a safe and efficient amphotropic packaging cell line. Virology. 167:400-406.

23. Fassati, A., Y. Takahara, F.S. Walsh, and G. Dickson. 1994. Production of high titre helper-free recombinant retroviral vectors by lipofection. Nucleic Acids Res. 22:1117-1118.

24. Danos, O. 1991. Construction of retroviral packaging cell lines. In Practical Molecular Virology. M.K.L. Collins, editor. The Humana Press Inc., Clifton, NJ. 24.

25. Takahara, Y., K. Hamada, and D. Housman. 1992. A new retrovirus packaging cell for gene transfer constructed from amplified long terminal repeat-free chimeric proviral genes. J. Virol. 66:3725-3732.

26. Fassati, A., D.J. Wells, F.S. Walsh, and G. Dickson. 1995. Efficiency of in vivo gene transfer using murine retroviral vectors is strain-dependent in mice. Hum. Gene Ther. 6:1177-1183.

27. Nicholson, L.V., K. Davison, G. Falkous, C. Harwood, E. O’Donnell, C. Slater, and J.B. Harris. 1989. Dystrophin in skeletal muscle. I. Western blot analysis using a monoclonal antibody. J. Neurol. Sci. 94:125-136.

28. Cullen, M.J., J. Walsh, L.V. Nicholson, J.B. Harris, E.E. ZubrzyckaGaarn, P.N. Ray, and R.G. Worton. 1991. Immunogold labeling of dystrophin in human muscle using an antibody to the last 17 amino acids of the $\mathrm{C}$-terminus. Neuromuscul. Disord. 1:113-119.

29. Man, N.T., A.J. Cartwright, G.E. Morris, D.R. Love, J.F. Bloomfield, and K.E. Davies. 1990. Monoclonal antibodies against defined regions of the muscular dystrophy protein, dystrophin. FEBS (Fed. Eur. Biochem. Soc.) Lett. 262:237-240.

30. Man, N.T., and G.E. Morris. 1993. Use of epitope libraries to identify exon-specific monoclonal antibodies for characterization of altered dystrophins in muscular dystrophy. Am. J. Hum. Genet. 52:1057-1066.

31. Sherrat, T.G., T. Vulliamy, and P.N. Strong. 1992. Evolutionary conservation of the dystrophin central rod domain. Biochem. J. 287:755-759.

32. Moore, S.E., and F.S. Walsh. 1985. Specific regulation of N-CAM/D2CAM cell adhesion molecule during skeletal muscle development. EMBO (Eur. Mol. Biol. Organ.) J. 4:623-630.

33. Dunckley, M.G., K.E. Davies, F.S. Walsh, G.E. Morris, and G. Dickson. 1992. Retroviral-mediated transfer of a dystrophin minigene into $m d x$ mouse myoblasts in vitro. FEBS (Fed. Eur. Biochem. Soc.) Lett. 296:128-134.

34. Flecknell, P.A. 1987. Laboratory Animal Anesthesia. Academic Press, London. $125 \mathrm{pp}$.

35. Caldwell, C.J., D.L. Mattey, and R.O. Weller. 1990. Role of the basement membrane in the regeneration of skeletal muscle. Neuropathol. Appl. Neurobiol. 16:225-238.

36. Kinoshita, I., J.T. Vilquin, B. Guerette, I. Asselin, R. Roy, and J.P. Tremblay. 1994. Very efficient myoblast allotransplantation in mice under FK506 immunosuppression. Muscle Nerve. 17:1407-1415.

37. Tinsley, J.M., D.J. Blake, R.A. Zuellig, and K.E. Davies. 1994. Increased complexity of the dystrophin-associated protein complex. Proc. Natl. Acad. Sci. USA. 91:8307-8313.

38. Campbell, K.P. 1995. Three muscular dystrophies: loss of cytoskeletonextracellular matrix linkage. Cell. 80:675-679.

39. Worton, R. 1995. Muscular dystrophies: diseases of the dystrophin glycoprotein complex. Science (Wash. DC). 270:755-756.

40. Cashman, N.R., J. Covault, R.L. Wollman, and J.R. Sanes. 1987. Neural cell adhesion molecule in normal, denervated and myopathic human muscle. Ann. Neurol. 21:481-489.

41. Dubois, C., D. Figarella-Branger, J. Nedelec, J.F. Pellissier, J. Boucraut, N. Bianco, and G. Rougon. 1990. Expression of various isoforms of neural cell adhesive molecules and their highly polysialylated counterparts in diseased human muscles. J. Neurol. Sci. 98:21-36.

42. Poole-Wilson, P.A., and P.H. Sugden. 1996. Physiological considerations: biochemistry and cellular physiology of heart muscle. In Oxford Textbook of Medicine. D.J. Weatherall, J.C.C. Ledingham, and D.A. Warrell, editors. Oxford Medical Publications, Oxford, United Kingdom. 2142.

43. Naldini, L., U. Blomer, P. Gallay, D. Ory, R. Mulligan, F.H. Gage, I.M. Verma, and D. Trono. 1996. In vivo gene delivery and stable transduction of nondividing cells by a lentiviral vector. Science (Wash. DC). 272:263-267.

44. Overturf, K., M. Al-Dhalimy, R. Tanguay, M. Brantly, C.-N. Ou, M. Finegold, and M. Grompe. 1996. Hepatocytes corrected by gene therapy are selected in vivo in a murine model of hereditary tyrosinaemia type I. Nat. Genet. 12:266-273.

45. Rafael, J.A., G.A. Cox, K. Corrado, D. Jung, K.P. Campbell, and J.S Chamberlain. 1996. Forced expression of dystrophin deletions constructs reveals structure-function correlations. J. Cell Biol. 134:93-102. 